Paper

\title{
Patterning collagen for 3D cell structures
}

\section{三次元状生体組織作製のためのコラーゲンパターニング}

\section{Shinjiro UMEZU and Tomohiko AOKI}

Dept. of Mechanical Engineering, Tokai Univ. 4-1-1 Kitakaname, Hiratsuka, Kanagawa, 259-1292 Japan

TEL: $x 81-0463-58-1211(E X .4356)$

e-mail:9aem1224@mail.tokai-u.jp

\section{Hitoshi OHMORI}

The Institute of Physical and Chemical Research(Riken), 2-1 Hirosawa, Wako Saitama 351-0198, Japan

TEL: $x 81$ - 048-462-1111

(Received 9 January, $2013 \quad$ Accepted 26 February, 2013)

The goal of this study is to fabricate 3-dimensional living tissue utilizing our ink-jet technology. Our inkjet technology has two merits; those were high resolution to print and ability to eject highly viscous liquid. In this paper, collagen was used as a scaffold material of the cells. Alginate gel is used as supporting scaffolds. We developed basic technology to fabricate 3-dimensional living tissue.

Keywords : Ink-jet, Cell, Collagen, Scaffold, Alginate

\section{INTRODUCTION}

近年，慢性的なドナー不足の深刻化や，難病の克服， 新薬の開発などを目的としたミクロな領域でのナノバイ 才分野での研究が注目を浴びている.ナノバイオ分野の 研究において代表例である iPS 細胞といったヒトの皮膚 細胞から万能細胞を作製させる技術を確立した山中氏が 先日ノーベル賞を受賞したが, iPS 細胞は, 再生医療分 野において，これらの問題解決の中核の技術になると考 えられている. ${ }^{1-5}$ 多くの細胞に分化できる上に患者本人 の細胞から作製が可能であるという理由から難病のメカ ニズムを解明し, 新薬を開発する研究が盛んに行われて いる. また, マクロな領域であるドナー不足の問題に関 しては, 現代医療では臓器移植なくしては, 治療できな い現状がある。しかしながら，ドナーが必要な患者に対 してのドナー数が圧倒的に不足している．これを人工的 に解決するためには, 患者由来の細胞を用いて, 立体の 臓器を人工的に作製する技術の確立が必要であると考え ている.これらよりミクロな領域でのナノバイオ分野の

SAS Award was given to this paper presented as Poster Presentation at the 2012 SAS Intelligent Symposium.
研究成果をマクロな領域での臓器などを対象とした研究 に応用するためにこれらをつなぐ中間の技術が必要不可 久である，そこで我々はこの再生医療分野における問題 を機械工学の視点から着目し，この中間の技術の達成を 目指している。具体的には，インクジェット技術を用い て, 細胞やバイオマテリアルを任意の箇所にプリントす るといったバイオプリントと呼ばれる分野の技術開発に 取り組んでいる．国内の研究において，インクジェット 技術を用いて三次元組織を作製するプロジェクトが富山 大学中村氏をリーダーとして行われている．中村氏の研 究はアルギン酸や細胞を三次元状にプリントし，チュー ブ等を作製している. ${ }^{6}$ しかし実際にスキャホールドとし て一般的なのはコラーゲンやフィブリンである。また， 3D の細胞組織を作製するプロジェクトとして大阪大学 松崎氏をリーダーとした研究が行われている．松崎氏は コラーゲンやフィブリンといった細胞外マトリックスを 用いて三次元状細胞組織を作製している. ${ }^{7}$ しかしながら， 細胞外マトリックスを用いてはいるがこれらのプリント は行われていない. それはコラーゲンといったバイオマ テリアルは高粘性な液体であり，これら高粘性な液体を 高精度にプリントすることが困難であるといった背景が 
あるからである. 一方で本研究室が保有している静電イ ンクジェット方式では, 高粘性な液体を高画質にプリン トすることが可能となっているため, 狙った箇所に細胞 や高粘性なバイオマテリアルを配置させることが可能で ある. ${ }^{8}$ したがって我々は高粘性な液体も同様にプリント し, 細胞だけでなくコラーゲンも狙った箇所にパターニ ングが可能となっている.

三次元状細胞組織の作製にあたり，実際の細胞組織は 足場となるスキャホールドが不可欠である. ${ }^{9-12}$ 現在, 細 胞の足場となるスキャホールドの作製に関する研究は非 常に多くなされており，エレクトロスピニング法を用い てのポリマーなどの合成高分子材料やコラーゲンといっ た天然高分子材料などがスキャホールドの材料として広

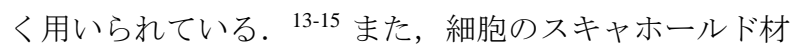
の応用例として, 臓器や軟骨, 神経や勒帯といった損傷 からの回復を助ける再生医療の研究も多く行われている. 16-22 また，バイオマテリアルであるアルギン酸ゲルの剛 性や親和性に着目した生体一の応用に向けた研究も盛ん に行われており, アルギン酸ゲルを用いた軟骨再生の研 究 ${ }^{23-26}$ やアルギン酸カプセル 27 を用いたアルギン酸ビー ズでの細胞培養, ${ }^{28-30}$ ビーズ内に薬を閉じ込め体内に搬 送するといったドラッグデリバリー ${ }^{31}$ などの研究が盛ん に行われている。これらより生体親和性が高く剛性の高 いアルギン酸ゲルを使用することが三次元状デバイスを 形成させるために好ましいと考えられる。

本研究では, 三次元状の生体組織作製のために細胞外 マトリックスであるコラーゲンに着目し，アルギン酸ゲ ル上にコラーゲンをプリントすることで, 細胞の接着 性・増殖性を向上させることが出来ると考えた. アルギ ン酸ゲル上に直接細胞をプリントし, 細胞の接着性およ び成長の様子を観察したところ, 接着の確認は出来たが 人工的に細胞組織を作製する上での細胞の増殖性として は不十分であった，その理由の一つとして細胞の足場と なるスキャホールドが十分に存在していなかったと考え られる. そこで, 体内にも存在する細胞外マトリックス であるコラーゲンをアルギン酸ゲル上にプリントするこ とで, 細胞の接着性・増殖性を向上させたので報告する.

\section{METHODS AND MATERIALS}

\section{II-A. Experimental equipment}

本研究では，インクジェット技術である静電インクジ エット方式を用いて細胞やバイオマテリアルをプリント し，三次元状の細胞組織を作製することを目的とする.

Figure 1 に示すような実験装置図を構成した. サンエイ テック社製注射器シリンジ $(10 \mathrm{ml})$ の先端にサンエイテッ
ク社製の導電性キャピラリーチューブ(I.D $0.33 \mathrm{~mm})$ を取 り付けた.シリンジに導電性の液体を満たしたものを液 体針電極とし，対向電極に対して垂直に設置する，パタ ーニングを行う対象物は対向電極上に設置する. シリン ジ内部に高電圧を印加することでノズル先端部と対向電 極間に静電力が発生し，ノズル先端部の液体がテーラー コーンと呼ばれる三角錐状の形状になる，その際にテー ラーコーンの先端から液滴がちぎれるように吐出するこ とでノズル径よりもはるかに細いプリントが可能である. またシリンジを覆うように保冷剤を設置し, 温度調整を 行うことで安定した吐出を可能にした，高電圧電源はグ リーンテクノ社製の GS50(電圧範囲:0 $50 \mathrm{kV}$ )を使用した. ノズル先端からシャーレ上の液体表面といった対象物と の電極間距離(gap)や印加電圧などの条件を変化させる ことでパターニングをコントロールする.

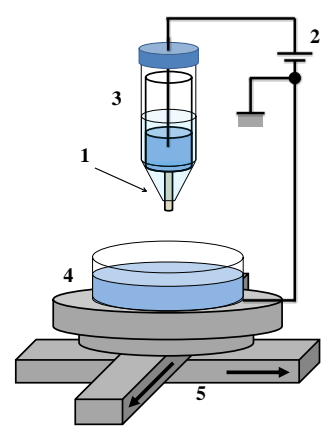

Fig. 1. Experimental set-up (1:nozzle, 2: high voltage apply, 3 : syringe covered with refrigerant, 4 :dish, 5:xyz linear stage) .

\section{II-B. Patterning collagen for 3D cell structures}

アルギン酸ゲル上に細胞を配置させるにあたり, 細胞 の足場となるスキャホールドを作製する必要がある。そ こで, 細胞外マトリックスであるコラーゲンをスキャホ ールドとして用いた.コラーゲンのパターニングにあた り，コラーゲンにおける基礎特性を調べた。使用したコ ラーゲンは新田ゼラチン社製の Cellmatrx Type1-A 培養 キットを用いて, コラーゲン, 濃縮培地, 再構成用緩衝 液を 7:2:1 の割合で混合させ使用した. コラーゲンの温 度は $5^{\circ} \mathrm{C}$ に保冷し, $\mathrm{pH}$ 值は 7.0 である。この時の粘度は 約 $20 \mathrm{mPa} ・ \mathrm{~s}$ であった．また，使用した細胞はウシの頸 動脈血管内皮細胞(HH 細胞)である.アルギン酸ゲル上に 細胞を配置するにあたり，塩化カルシウム $10 \%$ 水溶液を シャーレ上に浸し，アルギン酸ナトリウム $1 \%$ 水溶液を ノズル先端から吐出する。これによって厚さ $5 \mathrm{~mm}$ のア ルギン酸ゲルを作製した。作製したアルギン酸ゲル上に 直接 $\mathrm{HH}$ 細胞をプリントし，観察した。またアルギン酸 
ゲル上にコラーゲンをパターニングし，その上に細胞を 配置させてアルギン酸ゲル上における細胞の接着性・増 殖性を比較した。これらを行い，アルギン酸ゲル上にお ける細胞の接着性・増殖性の向上を確認した.

\section{RESULTS}

コラーゲンをスキャホールドとしてパターニングする にあたり,コラーゲンにおける基礎特性を明らかにした。 コラーゲンにおける各印加電圧と電極間距離を変化させ た時の吐出状態の領域を Fig.2 に示す. 電圧を印加し, Drop modeの領域に達すると液滴状に吐出し始め, さら に電圧を印加し, Droplet mode の領域となるとさらに小 さな液滴が吐出される. 印加電圧のさらに高い領域では スプレー状の吐出をする. Droplet mode は, 印加電圧の 範囲が狭く, Spray mode での吐出は比較的範囲が広いと いった特性がわかった. Droplet mode においてラインを 描いた際の印加電圧とライン幅の関係を Fig.3 に示す.

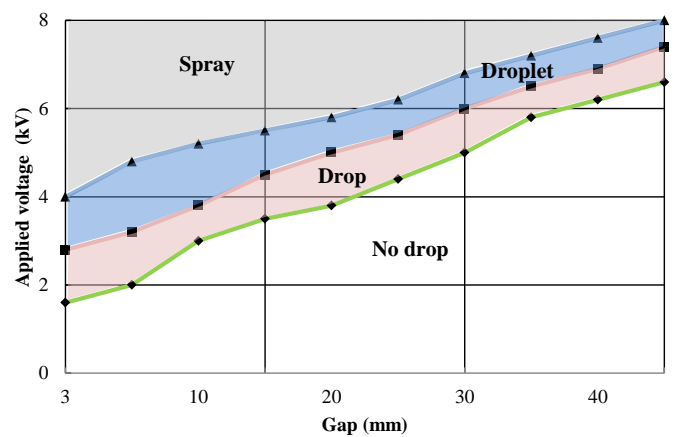

Fig. 2. Mode of droplet formation (Collagen is ejected.).

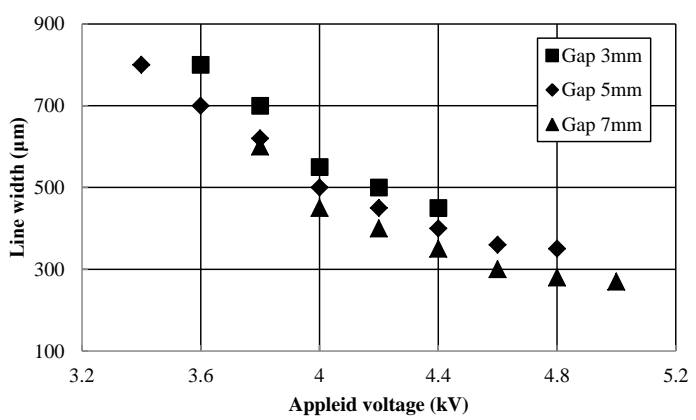

Fig. 3. Line width when the applied voltage is changed in case that gap is changed.

Figure 3 に示すように Droplet mode の領域において, ライン幅は印加電圧を上げることでライン幅は細くなっ ている.これは, 印加電圧が高くなるにつれてコラーゲ ンが引き寄せられる力が強くなり, ノズル先端から液体 がより細かくちぎれるようになったことが考えられる.
これらの特性を明らかにしたうえで，アルギン酸ゲル上 にコラーゲンをプリントする. Figure 4 に示すようにア

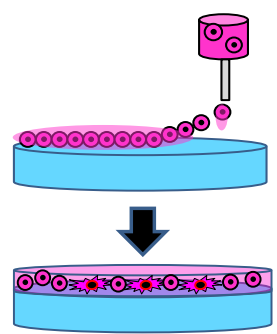

No collagen

(.) : Vascular endothelial cells. (Before the adhesion)

; Vascular endothelial cells. (After the adhesion)

$\ominus$; Collagen $\subseteq$; Alginate gel

Fig. 4. Schematic views.

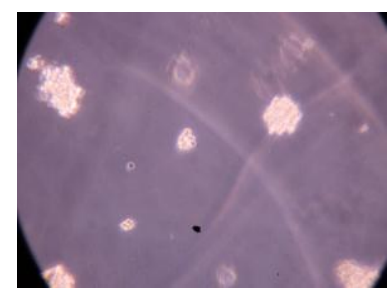

(a) After printing.

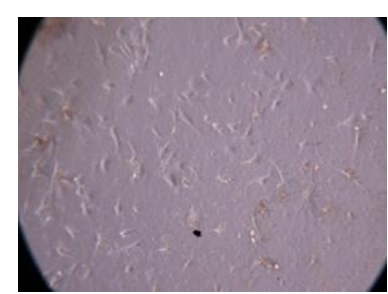

(b) It has passed 3days.
Fig. 5. Photographs of $\mathrm{HH}$ cells on alginate gel.

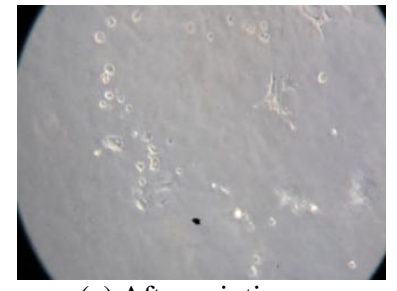

(a) After printing.

(c) It has passed 2days.

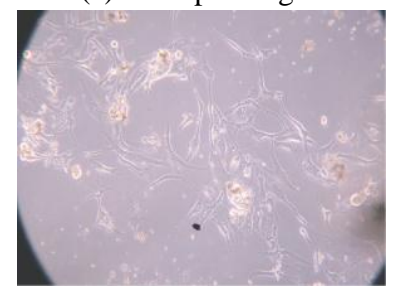

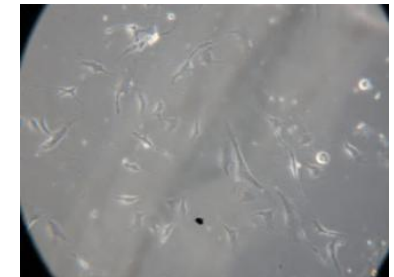

(b) It has passed 1day.

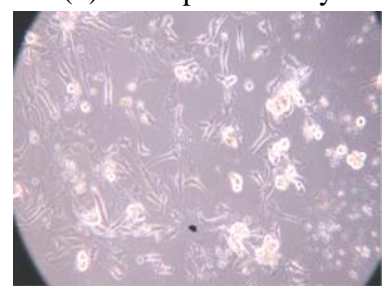

(d) It has passed 3days.
Fig. 6. Photographs of printed $\mathrm{HH}$ cells those are covered with collagen on the alginate gel.

ルギン酸ゲル上に細胞を配置させる上で，コラーゲンを プリントすることでより細胞の接着性・増殖性を向上さ せることが可能であると考えた。 そこでアルギン酸ゲル 上に直接細胞をプリントし，細胞の接着の観察をした写 真を Fig.5 に示す. 細胞が接着していることを確認した が，増殖性に関しては不十分であった．次にアルギン酸 ゲル上にコラーゲンをスキャホールドとしてプリントし， 細胞を同様に観察した結果を Fig.6 に示寸.コラーゲン 
をパターニングすることで細胞は接着し，しっかりと増 殖しているのが確認出来る。これらの結果は, アルギン 酸ゲル上の表面がスキャホールドとして好ましくない足 場であったと考えられる. そこで細胞外マトリックスで あるコラーゲンをアルギン酸ゲル上にパターニングする ことで表面が細胞の接着に好ましい足場となったために 細胞の接着性や増殖性が大きく向上したものと考えられ る.これは人工的に三次元状生体組織を作製するための 作製時間の短縮につながり, 非常に重要であるといえる.

\section{CONCLUSION}

三次元状生体組織作製において，アルギン酸ゲル上に コラーゲンをスキャホールドとしてパターニングするこ とで細胞の接着性・増殖性を向上することが出来た. こ れらの結果より, コラーゲンを用いてアルギン酸ゲルを 骨組みとした三次元生体組織の作製が期待出来る.

\section{ACKNOWLEDGEMENTS}

本研究では, 科研費若手 $(\mathrm{B})$ の助成を受けて推進されま した．付記して，謝意を表します。

\section{REFERENCES}

${ }^{1}$ S. Yamanaka, Cell, 137, pp.13-17 (2009).

2 Y. Yoshida, S. Yamanaka, Journal of Molecular and Cellular Cardiology, 50, pp.327-332 (2011).

${ }^{3}$ K. Takahashi, S. Yamanaka, Cell, 126, pp.663-676 (2006).

${ }^{4}$ D. Taura, M. Noguchi, M. Sone, K. Hosoda, E. Mori, Y. Okada, K. Takahashi, K. Homma, N. Oyamada, M. Inuzuka, T. Sonoyama, K. Ebihara, N. Tamura, H. Itoh, H. Suemori, N. Nakatsuji, H. Okano, S. Yamanaka, K. Nakao, FEBS Letters, 583, pp.1029-1033 (2009).

5 N. Yokoo, S. Baba, S. Kaichi, A. Niwa, T. Mima, H. Doi, S. Yamanaka, T. Nakahata, T. Heike, Biochemical and Biophysical Research Communications, 387, pp.482-488 (2009).

${ }^{6}$ M. Nakamura, M. Mie, H. Mihara, M. Nakamura, Eiry Kobatake, Biomaterials, 29, pp.2977-2986 (2008).

${ }^{7}$ P. Chetprayoon, K. Kadowaki, M. Matsusaki, M. Akashi, Acta Biomaterialia, 9, pp.4698-4706 (2013).

${ }^{8}$ S. Umezu, T. Kitajima, H. Ohmori, Y. Ito, Sensors and Actuators A: Physical, 166-2 pp.251-255,
(2011).

${ }^{9}$ D. Dado, S. Levenberg, Seminars in Cell \& Developmental Biology, 20, pp.656-664 (2009).

${ }^{10}$ F. Causa, P. A. Netti, L. Ambrosio, Biomaterials, 28, pp.5093-5099 (2007).

${ }^{11}$ J. Wang, F. Jia, T. Gilbert, S. Woo, Journal of Biomechanics, 36, pp.97-102 (2003).

${ }^{12} \mathrm{~S}$. Cai, J. Xi, Computer-Aided Design, 40, pp.1040-1050 (2008).

${ }^{13}$ M. Horst, S. Madduri, V. Milleret, T. Sulser, R. Gobet, D. Eberli, Biomaterials, 34, pp.1537-1545 (2013).

${ }^{14}$ K. Chatterjee, L. Sun, L. Chow, M. Young, C, Simon Jr, Biomaterials, 32, pp.1361-1369 (2011).

${ }^{15}$ S. Joughehdoust, A. Behnamghader, M. Imani, M. Daliri, A. Hashemi Doulabi, E. Jabbari, Ceramics International, 39, pp.209-218 (2013).

${ }^{16}$ C. Huang, R. Chen, Q. Ke, Y. Morsi, K. Zhang, X. Mo, Colloids and Surfaces B: Biointerfaces, 82, pp.307-315 (2011).

${ }^{17}$ C. Shi, Q. Li, Y. Zhao, W. Chen, B. Chen, Z. Xiao, H. Lin, L. Nie, D. Wang, J. Dai, Biomaterials, 32, pp.2508-2515 (2011).

${ }^{18}$ B. Kanungo, E. Silva, K. Van Vliet, L. Gibson, Acta Biomaterialia, 4, 490-503 (2008).

${ }^{19}$ S. Park, E. Gil, H. Shi, H. Kim, K. Lee, D. Kaplan, Biomaterials, 31, pp.6162-6172 (2010).

${ }^{20}$ N. Nagai, S. Yunoki, T. Suzuki, M. Sakata, K. Tajima, M. Munekata, Journal of Bioscience and Bioengineering, 97, pp.389-394 (2004).

${ }^{21}$ B. Kanungo, L. Gibson, Acta Biomaterialia, 6, pp.344-353 (2010).

${ }^{22}$ B. Kim, Y. Kang, J. Phi, Y. Kim, D. Hwang, J. Choi, S. Ryu, A. Elastal, S. Paek, K. Wang, S. Lee, S. Kim, B. Yoon, Cytotherapy, 12, pp.841-845 (2010).

${ }^{23}$ Y. Kuo, C. Chung, Biomaterials, 33, pp.8955-8966 (2012).

${ }^{24}$ Y, Lee, S. Polio, W. Lee, G. Dai, L. Menon, R. Carroll, S. Yoo, Experimental Neurology, 223, pp.645-652 (2010).

${ }^{25}$ T. Re'em, O. Tsur-Gang, S. Cohen, Biomaterials, 31, pp.6746-6755 (2010).

${ }^{26}$ R. Rezende, M. Rezende, P. Bártolo, A. Mendes, R. Filho, Computer Aided Chemical Engineering, 27, pp.1935-1940 (2009). 
${ }^{27}$ J. Wikström, M. Elomaa, H. Syväjärvi, J. Kuokkanen, M. Yliperttula, P. Honkakoski, A. Urtti, Biomaterials, 29, pp.869-876 (2008).

${ }^{28}$ G. Klinkenberg, K. Lystad, D. Levine, N. Dyrset, Journal of Dairy Science, 84, pp.1118-1127 (2001).

${ }^{29}$ I. Constantinidis, I. Rask, R. Long Jr, A. Sambanis,
Biomaterials, 20, pp.2019-2027 (1999).

${ }^{30}$ S. Huang, M. Wu, G. Lee, Sensors and Actuators B: Chemical, 147, pp.755-764 (2010).

${ }^{31}$ K. Koyama, M. Seki, Journal of Bioscience and Bioengineering, 97, pp.111-118 (2004). 